\title{
Determinants of Bank Profitability
}

\author{
*Yasmeen Sultan
}

Hamdard University Islamabad, Pakistan

\begin{abstract}
Banks are the most vital financial intermediaries in economy, which has a profitable banking industry; in order to survive undesirable shock as well as subsidize the constancy under the whole economy. However, the main purpose of this research is in the direction of analyzing factors affecting banks' effectiveness all over Pakistan by means of sets of targeted facts and figures of twenty panels from 2005 to 2015. This study is developed with the help of AOLS technique which is used to examine the effect of different factors such as resources, debts, justice, securities, economic growth, price increases, price decreases, and market capitalization on major profitability signs such as (ROA), (ROE), (ROCE) and (NIM). The experimental consequences analyzed solid facts which stated the following conclusion, i.e., internal factors and external factors create an adverse impact on the level of profitability. An outcome by this research is important to different researchers. This research study proposed that by the concentration \& reengineering the internal drivers the banks can improve its profitability and performance.
\end{abstract}

\section{Introduction}

Profitability demonstrates a connection between a total sum of income which specifies the capacity of a bank in raising its funds to the customers and thereby increasing their profit level (Chatterjee et al., 2014). It also defined as the capability to generate revenue occurring in business transactions in organizations. It also displays the way in which it is competently making profits by using its all existing resources in the market. According to Harvard and Upton, profitability is the the ability of given investment to earn a return from its use.

The profitability of the banks and any other organizations is restrained by expenses and income. Income is the money produced by the organization's activities. Expenses are the cost of resources used up or expended by the organization activities (Davydenko, 2010). The relationship between banks profit and business progression is significantly evaluated with the reliability \& stability of different banks rate (Albert, 2015). On a higher level, the money making and productive banks are very suitable in filling harmful situations and can increase the power of monetary organization (Aburime, 2008). According to Athanasoglou et al. (2008) money making and reliable banks should have greater polices to sustain in adverse distresses and complement the stability in an economic organizations. Financial organizations play a vital part in the development of the economy and growth.

*Corresponding author.

Email: yasmeensultan291@gmail.com 
The existence of non-financial banks and financial banks provides efficient cash for investing in the markets to maintain their economic growth \& development. Financial banks play a vital role for economic intermediation with the help of gathering \& organizing resources for the finance industry projects, which are necessary for financial development of organizations.

The financial banks are appropriate for monetary intermediation, which support private division of investments and promote the entrepreneurs; whereas, monetary organizations integrate with characterized into banking system \& non- banking monetary organizations.

According to (Bawumia and Owusu-Danso, 2008), the Pakistani banks calculated 70\% of financial region, have a hostile universe impact on the economy. In this study, the word bank profitability is used to rise to bank profitability and performance/growth.

The Pakistani banking sector has faced and observed numerous improvements and reengineering for many years as a consequence of interior and exterior economic growths and tremors. The latest expansions in banking sector are implementation of (IFRS) in link with international standards by the State Bank of Pakistan, with the method of decreasing its total threat.

In most research studies the banking sector has been making more improvements that have altered the investment productiveness; while the classification of finance area that has improved, is motivated by banks liberalization, superior and rivalry (Bawumia and Owusu-Danso, 2008). Therefore, realistic to expect these improvements have been transformed to Pakistani banks and their performance.

The significance of this research study is based on profitability of banks statements consequences that is the main division in the banking sectors. Therefore, these consequences are not only successful for banking sector but also profound for big economy. Secondly, the banks are restructuring an expected distress method and working on their presentation. Finally, banks profitability is more significant due to retained earnings. Bank capitalization provided a scope of protection during declining time period and supporting banks, further resilient opposition to exterior shocks. In this research study we will examine some key determents of banks profitability and the level to which it has an impact on banks factors.

The inspiration of this research study is based on advance recommendation that could be verified \& further used for decision making purpose regarding administration organization polices and banks profitability level. This research study also observed the inspecting factors that have an effect on the banking sector's profitability \& degree to which the banking sectors profits are affected by these factors are. This recommendation is not only useful for Pakistan banks but also for economies in every Region.

\subsection{Background}

Profitability is basically an accounting concept that shows the excess of profits over expenses for a quantified era of the moment that characterizes earning of the banking sector for the reason of which they accomplish a variety of actions in the rising financial system of Pakistan. The Profitability of the banking sector is a silent characteristic \& support of the argument as knowledgeable of the business individual.

The banking sector of every country acts as a life blood of modern trade \& commerce, which provides major source of financing. The increasing phenomenon in the world has made the concept of both financial and non-financial institutions and banks a major part of efficiency and effectiveness. The financial system is dominated by commercial banks in Pakistan. The structure of banking system has made significant changes since 1997.

This research study proposed the determinants of profitability for banks divided into two 
parts; internal factor are microeconomics and the external factors are macroeconomics. The importance of banks profitability is treasured at the small \& higher levels of the economy. This research study also observed the both aspects microeconomic \& macroeconomic stability, as well as economic growth.

At the micro-level, profit is the essential requirement of a bank institute and the supply of reserves. In the banking sector, the factors of profitability are well researched. The profitability measurement diverges from study to study. The two main elements of profitability are (ROA), and (NIM).

\subsection{Objectives of the Study}

The purpose of this research study is to notice the effects of determinants of profitability on banks. According to our study, we can analyze the level of bank information from 2005 to 2015 \& considering the method of the panel data regression to discover the connection among main factors in seventeen banks of Pakistan \& their special impacts on the high level of bank profitability. Our study varies because we are directing this in the Pakistani environment.

\subsection{Significance of Study}

The significance of this study will restrict to examine the impact of factors which are internal and external and can influence bank profitability. These factors involve capital adequacy, expenses management, liquidity, asset quality, GDP, size, money contribution, inflation, \& banking sector of Pakistan. It confirmed that there are some variables that have an impact on the bank's profitability, but they are not included into project.

Some other banking factors contain unlimited regulation indicator, taxations, political factors, cooperate governance, technology advancement \& quality of services. The main vision allowance of projects looks at bank sectors internal and external factors to increase and maintain profitability of banks.

One more probable accumulation on the inspection of alterations in banks Profitability determination of all banks sectors, i.e. small or large or high-profit or low-profit banks. This research study includes a sample of twenty-six banks from the period of 2005-2015.

\subsection{Gap Identification}

As we observed that there is strong positive relationship between different factors and bank's profitability. This research study used different economics models for profitability of banks. And there is a very limited research study done in the context of the Pakistan banking sector. We have used (LOAN); (CAPITAL); (SIZE) (DEPOSITS) (ROA); (ROE); (ROCE) \& (NIM).

\section{Literature Review}

\subsection{Profit Measures and Determinants of Banks Profitability}

There are different types of research work done to determine the factors that affect banks profit level. It is most important, while considering bank and its profitability to obtain factors associated with account. For this purpose the detail of factors has been mentioned below, having a substantial impact on banks \& profit level. 
According to Rasiah (2010) some scholars have mainly focused on factors determining banks profitability and their performance with two different groups. First one is internal factor and second one is external factor of banks. They also argued that price does not change when profitability ratio is used. In fact it is the most appropriate method to determining profitability after properly analyzed. Rasiah (2010) also studied two different types of ratios, e.g. return on equity \& return on the asset.

\subsubsection{Return on assets (ROA)}

The Return on Assets (ROA) an indicator of banks profitability is relative to its total assets. ROA gives idea of how efficient bank management is, using its assets to generate earnings. ROA displays a percentage; if it is higher the ROA is better. The greater level of ROA ratio shows that bank performance is better. Its an important mechanism for profitability in banks \& entire banking organization. As compare to some other research study, some scholars work in ROA ratio percentage, which is a suitable measurement for bank profitability.

\subsubsection{Return on Equity (ROE)}

This ratio provides how efficiently banks handle money management, which contributes to its shareholders. ROE measures the profitability of banks and other organizations. Higher the ROE means banks are efficient in generating income \& growth from its equity financing.

\subsection{Internal Factors of Bank Profitability}

According to Hosni et al. (2011) internal factors of bank profitability usually include those factors which are in control of banks. These factors affect income and price of banks. Many researchers have recognized two types of groups. One is financial statement of variables and other one is non-financial statement of variables. The financial statement of variables is directly connected to the balance sheet \& Income statement of banks.

\subsubsection{Income}

According to Radian (2019), the banking sector produces more income from their assets as compared to non -banking sectors. He further recognized two types of income; Interest \& Non interest Income. Interest Income includes rates obligatory on lands, overdraft, \& trading money that banks propose to their customers. Second type of Income is non-interest income which includes returns on reserves, brokerage charges, dues, retreats \& commission in companies.

Tan and Floros (2012) has observed that the main factor of banks profit is income which comes from interest rate. He also observed that there is approximately $80 \%$ income from interest rate. On the other hand, banks embrace bonuses and get benefits from trading security markets.

\subsubsection{Loan Quality}

The main part of banking sectors is lending money to its borrowers, which serves as one of the major sources of income. Previous studies determined one more elastic resource on balance sheet of banks.

It is clear that when banks offer more loans, they get more profits and generate more revenue through this policy of loan quality. 


\subsubsection{Deposits}

Banks are deeply depending on treasuries that are given by General Community to deposit of funding the lending of money, which is accessible to banks consumers. Additionally, mostly individuals considerate with the intention of loans are not large in demand, As more deposits in banks decline earnings, which are low profit for the banks. According to some other researchers, there is reason for deposit, time, Fixed, Term deposit appeal high interest rate from banking sectors to its depositors.

\subsubsection{Capital Ratio}

According to Rasiah (2010) the capital ratio is a percentage of banks Capital to its weighted assets. Mostly Banks in undeveloped countries require a large amount of investment because it gives strength to survive in economic crisis \& also provide secure shield in situations of insolvency conditions to their investors. Banks on the level of justice decrease their expense on capital gain which has positive effect on profitability of banks. In addition, common banks are insolvencies due to lack of money, which is necessary for banking sectors for greater capital in stress periods.

\subsubsection{Liquidity Ratio}

Rasiah (2010) stated that for the most part banks are essential with supervisor to grasp a specific level of liquidity resources. They also claimed that if banks gathered sufficient cash in results, they obtain high liquidity, with capability of increasing the raw materials earlier, as compared to other sources, which are capable to assemble and economic obligations. They also observed that there is slow earning on assets and high liquidity on unnecessary reserves. There are negative impacts on banks profitability level.

\subsubsection{Non-interest Income}

Non-interest Income is the Income embodied from other sources, like earning from loans of banks. The sources of non-interest income are different types, which include fees earned from contribution unit trust service \& service charges on the bank's deposit account, etc.

According to Rasiah (2010) old banking businesses as compared to other financial institutions are varying towards the financial globalization \& liberalization; due to these reasons banks are able to increase profits and income. The experimental results Krakah and Ameyaw (2010) study observed that the income from non interest is very important element of profitability of Pakistani banks. And according to them, there is always a positive association between banks' profitability and non-interest income of the banks.

\subsubsection{Expenses}

Torre Olmo et al. (2021) posited that expenses of banks imitate the banks expenditure that is happening during the control of management of banks. This is categorized into two parts, i.e. non- interest expenses \& interest expenses. Expenses which are incurred by different banks while making revenue as an Interest which can be paid out to depositor, and called an interest expense.

In contrast, Non-expense Interest includes wages paid to employees, salaries, operating expenses, overhead expenses, \& miscellaneous expenses. According to two different researchers Bourke (1989) and Jiang et al. (2003) show a negative relationship between profitability and expenses, which indicates mostly banks having low cost result in high profits. 


\subsubsection{Taxation}

Vong and Chan (2009) separated some variables, i.e. tax variable \& those taxes which operate profit before tax. This research study is treated as a unique research study as compared to other researcher work by Gyamerah and Amoah (2015). He postulated that taxes are the expense variable, doesnt matter how they show.

Vong and Chan (2009) claimed that an affirmative association occurs between the profitability and tax. Furthermore, Chioma and Orga (NA); Demirgüç-Kunt and Huizinga (1999); Vong and Chan (2009) specified a positive association between banks profitability and the tax variable.

\subsection{External Variables of Banks Profitability}

External variables are that factors which affect banks profitability and are not controlled by the management of banks. These are indirect variables that have an extreme effect on the profit level of banks.

As per Krakah and Ameyaw (2010) research study the macroeconomic factors are used to determine the external determinants. This includes GDP, interest rate, competition, inflate rate, size.

\subsubsection{GDP}

Vong and Chan (2009) investigated that the economic growth is directly determined by GDP which has positive relation with bank profit level. Larger monetary development organizations show large demand for lending money which comes from the result of interest and non interest incomes.

This research study determined that the profitability has directly positive association between two variables which are inconsistent and negative relationship between two variables which are consistent. In conclusion, GDP economic growth has positive relationship with banks profit level, which increases overall level of profitability of banks.

\subsubsection{Rate of Interest}

Davydenko (2010) believed that bank's interest rate is taken from different factors, consequently net income interest rate having a huge impact on bank profitability level. A change in interest rates has had a greater effect on banks' profit levels. It has a direct relationship with the banks. In other words, there is a direct relationship, i.e. if the interest rate increases, bank's profitability level also increases, and on the other hand if the interest rate decreases the banks profitability level also decreases. Fluctuations in interest rate can be of long term period as well as short term period, depending on the situation.

\subsubsection{Rate of Inflation}

According to Revel (1979) inflation is one of the main factors that can cause changes in the profitability of the banks. By the definition of different researchers inflation increases the price level in a country. Due to which, when inflation rate increases, banks profitability decreases, having inverse relationship between them. Consequently, inflation creates pressure on bank profitability.

On the other hand when inflation rate decreases, it automatically increases the banks profitability level. Therefore, the current study hypothesize that inflation rate has a negative relation with banks profitability. The inflation rate is a serious problem that can be managed by the 
government of every country. In case of serious situations, the banks responsibility is to take precautionary steps to maintain banks profitability.

\subsubsection{Competition (Market Share/Market Growth Rate)}

There are some competitive forces which affect banks profitability level. These are called drivers of opposition. It becomes challenging for a firm to increase its profit level when faced with strong competitive forces. A study by Mill et al. (1986) observed that a strong relationship has positive effects on bank profitability level.

\subsubsection{Market Growth}

According to Bourke (1989) market growth is a greater way of entry barriers, and barriers are great for banking sector, as they increase profitability level.

\subsection{Framework}

Determinants of Banks' Profitability

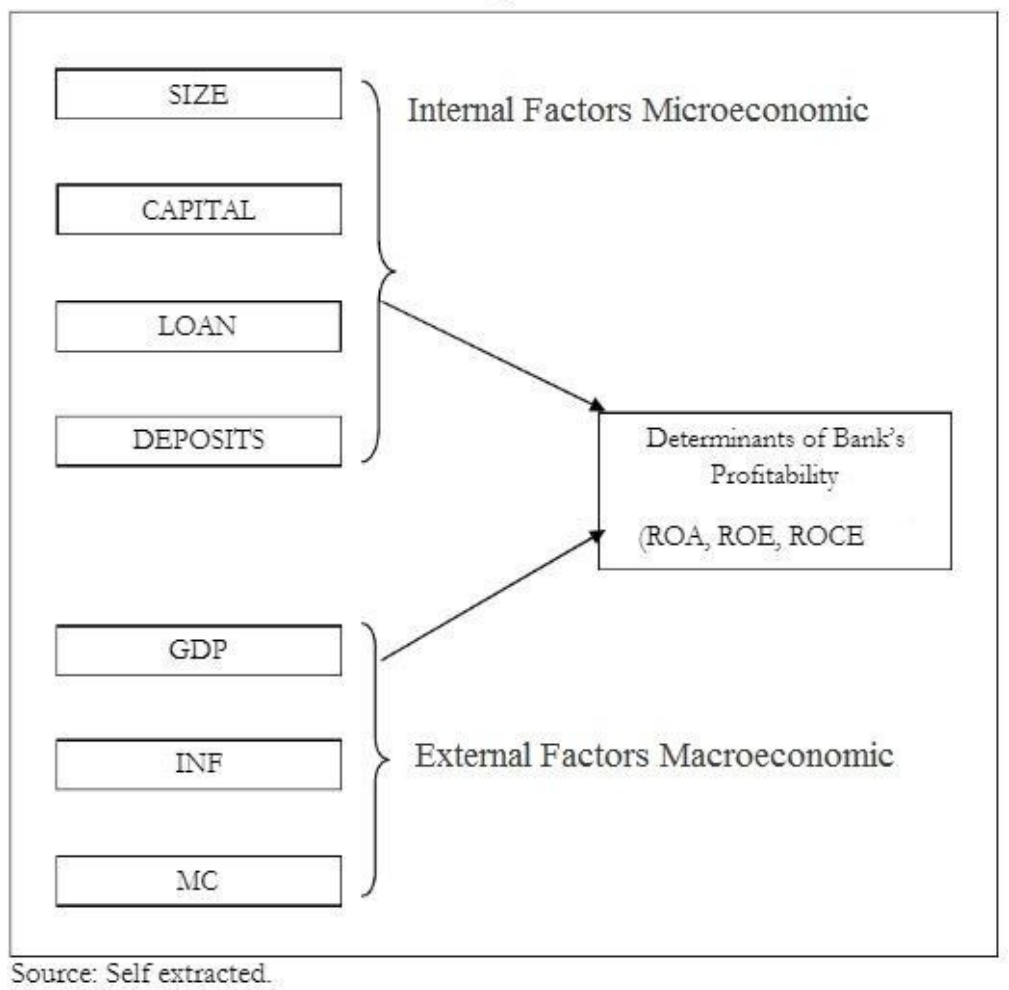

Figure 1: Framework 


\section{Framework and Methodology}

This chapter of research study includes methodology, hypotheses, framework, and measures of variables. The last part of this chapter includes data and sample selection with the tested and verified modes.

\subsection{Hypotheses}

Based on the objectives and reviewed literature, the hypotheses are as followed:

$H_{1}$ : There is positive relationship between internal factors $\mathcal{E}$ profitability of Banks.

$H_{1 a}$ : There is positive relationship between DEPOSITS \& profitability of Banks.

$H_{1 b}$ : There is a positive relationship between LOAN E profitability of Banks.

$H_{1 c}$ : there is negative relationship between CAPITAL \& profitability of Banks.

$H_{1 d}$ : There is a relationship between SIZE E profitability of Banks.

$\mathrm{H}_{2}$ : There is a positive relationship between external factors $\mathcal{E}$ profitability of Banks.

$H_{2 a}$ : There is a positive relationship between MC and profitability of Banks.

$H_{2 b}$ : There is a positive relationship between INF and profitability of Banks.

$\mathrm{H}_{2 c}$ : There is a positive relationship between GDP and profitability of Banks.

\subsection{Measures of Variables}

It includes all the variables that affect the profitability of a bank. They are as followed:

ROA is return on an asset which is calculated by dividing the net income with total assets. Is a ratio identified by dividing the net income over total assets?

ROE is return on equity which is calculated by dividing net income to total shareholders equity.

ROCE is return on capital employed which is calculated by non- mark-up income to capital employed.

NIM is net interest margin and it is a degree of the difference between the interest income produced and interest paid out to their lenders.

SIZE concludes the information that superior banks have better economies of scale as compared to the smaller banks.

CAPITAL is considered as the ratio of equity capital to total assets. The lesser the capital will be more will be the banks profitability.

INF The rate of inflation on banks entirely depends on the inflation rate in Pakistan. Low inflation is not good for country and banks performance. While high inflation creates an adverse effect. Due to this reason, the bank always takes precautionary measures to avoid the risk of bankruptcy. 
Market Capitalization (MC) it is measured by adding both debt and equity financing.

\subsection{Data and Sample Selection}

\subsubsection{Survey Design}

This section explains that both the external \& internal factors have an impact on the banks profitability of Pakistan. In order to achieve the above study goal, the scholar chooses review research as a policy of investigation.

In current study one sample is examined by different tests. Secondly, it provides an opportunity for the examiner to capture the sample database on the experimental figures. And the third one is survey design. This will help it become economically feasible. In other words, it captures a huge quantity of data in a small period of time with very little expense. Consequently, the data for this research study has been composed by using structured biography analyses of banks' financial statements. Moreover, data is based on the cross- sectional survey. This section shows a detailed analysis of survey documents, data analyses, and sample design.

\subsubsection{Sample Design}

This sample design seeks to explain both internal and external factors that affect the profitability of Pakistani banking system. Therefore, for current study the target population was all banks recorded by SBP and currently operating in a country. Presently, in Pakistan, there are forty-seven banks operating. The banks contain four foreign banks, five Islamic banks, fifteen private banks, four specialized banks, five public sector banks, thirteen microfinance banks, and one development finance institutions.

10 years of data is needed for the study, therefore, most recently established private banks are eliminate from the research work so, the number of banks is decreased to 20 . The researchers do not consider the sample size is adequate to make an evaluation of the population because the sample ensures only $45 \%$ of the total population.

\subsubsection{Data Collection}

In this research study to observe the impacts of different factors on banks' profitability, financial statements of banks are reviewed. Study used ten years of data for analysis, i.e. time period 2005 to 2015. Secondary data, collected from the SBP and other related websites of banks was used.

\subsubsection{Empirical Model}

This research model is used for the purpose of combination of cross- sectional with time series to make it panel data. Ertekin et al. (2019) examined that panel data allows economists \& some academics to investigate in details for the results analysis. In this research we used a quantitative and descriptive Measure.

\subsubsection{Descriptive Statistics}

According to Greene (2008) descriptive statistics is the self- control of quantitatively defining the main features of selected information. Its targets are concluding a set of samples. Some methods are used to define a set of data that measures central tendency, variability and dispersion. Measurement of central tendency consists of maximum, minimum, standard deviation, mean, median, and value for each variable. 


\subsubsection{Correlation}

Correlation is any statistical relationship, either causal or not, between two random variables or two sets of a data sample. It includes dependence or the degree to which two variables have a linear relationship with each other.

\subsubsection{Study Model}

The simple approximation strategy is to group the observations and apply the regression analysis on the organized sample.

Following is the study model in an equation form

$\mathrm{Y}_{i t}=\alpha_{0}+\alpha_{l} \mathrm{X} 1_{i t}+\alpha_{2} \mathrm{X} 2_{i t}+\alpha_{3} \mathrm{X} 3_{i t}+\alpha_{4} \mathrm{X} 4_{i t}+\alpha_{5} \mathrm{X} 5_{i t}+\alpha_{6} \mathrm{X} 6_{i t}+\alpha_{7} \mathrm{X} 7_{i t}+\mu_{i t}$

Where;

$\mathrm{Y}$ it indicates (ROA), (ROE); (ROCE) and (NIM) for bank I at time $t$.

$\mathrm{X} 1$ it indicates (SIZE) for bank $\mathrm{I}$ at time $\mathrm{t}$

$\mathrm{X} 2$ it indicates (CAPITAL) for bank $\mathrm{I}$ at time $\mathrm{t}$

$\mathrm{X} 3$ it indicates (LOAN) for bank I at time $t$

$\mathrm{X} 4$ it indicates (DEPOSITS) for bank $\mathrm{I}$ at time $\mathrm{t}$

This is the best process in which the connection between factors remain constant in the cross sectional method. The data of this research study is regarding the Pakistan banks. We also used an Ordinary Least Square method for analysis.

\section{Results}

This section is about the results of the research study. This part of research study includes descriptive statistics, correlation, and econometric methods for analysis.

- $\mathrm{X} 5$ it indicates (GDP) for bank $\mathrm{i}$ at time $\mathrm{t}$

- $\mathrm{X} 6$ it indicates (INF) for bank $\mathrm{i}$ at time $\mathrm{t}$

- $X 7$ it indicates (MC) for bank $i$ at time $t$

- $\mathrm{i}=1$ to 20 banks

- $\mathrm{t}=2005-2015$

- $\mathrm{u}=$ Error term.

\subsection{Descriptive Statistics}

The Descriptive statistical table shows dependent and independent variables impact on Pakistani banks profitability for the periods of ten years 2005 to 2015 and 832 are interpretation in Pakistan. According to McClendon and Buckner (2007), descriptive statistics table also comprises the mean, standard deviation, median, sample variance, skewness, sum, number of observations, maximum, and minimum for the independent and dependent variables of the model.

ROCE, ROE, ROA, and NIM, all of them have a positive mean values that varies from a low of 0.072 to 27.28 . The table also consists of banks with very dissimilar dimensions. Standard Deviation of NIM is 0.025 which represents the observations in data set and closer to the mean value. The uppermost standard deviation for ROCE and ROE is 18.76 and 15.58 correspondingly. 
Table 4.1: Descriptive Statistics

\begin{tabular}{lccccccccccc}
\hline & ROA & ROE & ROCE & NIM & SIZE & CAPITAL & LOAN & DEPOSITS & GDP & INF & MC \\
\hline Mean & 1.03 & 12.24 & 27.28 & 0.072 & 18.54 & 0.113 & 0.51 & 0.798 & 5.46 & 9.94 & 8.74 \\
Median & 1.3 & 15.02 & 28.02 & 1.02 & 18.74 & 0.101 & 0.62 & 0.805 & 6.12 & 7.96 & 8.96 \\
Std Deviation & 1.84 & 15.68 & 18.76 & 0.025 & 1.31 & 1.032 & 0.11 & 0.049 & 1.47 & 5.41 & 0.21 \\
Minimum & -7.81 & -73.2 & 0.61 & 0.06 & 15.8 & 0.03 & 0.23 & 0.895 & 2.71 & 4.81 & 8.34 \\
Maximum & 3.72 & 37.59 & 56.3 & 0.125 & 20.36 & 0.49 & 0.49 & 1.689 & 6.65 & 20.02 & 9.15 \\
\hline
\end{tabular}

\subsection{Correlation with respect to $\mathrm{ROA}$}

There is a larger deviation in data set of ROCE by the different banks sizes. The connections among variables are identified with the help of ROA, ROCE, \& ROE. As shown in Table 2, 3, $\&$ the 4 . The indicated table of this research shows that there is a positive relationship between GDP, INF, SIZE, LOAN, \& DEPOSITS. While a negative connection between MC and CAPITAL to ROA.

Table 4.2: Correlation in relation to ROA

\begin{tabular}{lcccccccc}
\hline & ROA & SIZE & CAPITAL & LOAN & DEPOSITS & GDP & INF & MC \\
\hline ROA & 1 & & & & & & & \\
SIZE & 0.378 & 1 & & & & & & \\
CAPITAL & -0.521 & 0.104 & 1 & & & & & \\
LOAN & 0.25 & 0.291 & -0.132 & 1 & & & & \\
DEPOSITS & 0.38 & 0.625 & 0.287 & 0.187 & 1 & & & \\
GDP & 0.396 & -0.169 & -0.158 & 0.269 & 0.148 & 1 & & \\
INF & 0.251 & 0.178 & 0.006 & -0.241 & 0.042 & -0.889 & 1 & \\
MC & -0.325 & 0.452 & 0.289 & 0.212 & 0.256 & 0.235 & -0.135 & 1 \\
\hline
\end{tabular}

\subsection{Correlation in relation to $\mathrm{ROE}$}

According to this research analysis Table 3 indicates a correlation analysis between ROE and explanatory variables of the research. It shows almost the same results as per with ROA. This is because both profitability \& ROA has a positive relationship with each other.

\subsection{Correlation in relation to ROCE}

In the table 4, it shows that INF and GDP is positively connected with LOANS, CAPITAL, MC, SIZE and DEPOSITS, while negatively related to ROCE. This shows that larger banks have a lower rate of ROCE. 
Table 4.3: Correlation in relation to ROE

\begin{tabular}{lcccccccc}
\hline & ROE & SIZE & CAPITAL & LOAN & DEPOSITS & GDP & INF & MC \\
\hline ROE & 1 & & & & & & & \\
SIZE & 0.379 & 1 & & & & & & \\
CAPITAL & -0.365 & 0.365 & 1 & & & & & \\
LOAN & 0.652 & 0.354 & -0.132 & 1 & & & & \\
DEPOSITS & 0.369 & 0.785 & 0.235 & 0.187 & 1 & & & \\
GDP & 0.365 & -0.458 & -0.158 & 0.269 & 0.254 & 1 & & \\
INF & 0.125 & 0.548 & 0.254 & -0.241 & 0.042 & -0.889 & 1 & \\
MC & -0.265 & 0.254 & 0.289 & 0.171 & 0.256 & 0.254 & -0.234 & 1 \\
\hline
\end{tabular}

Table 4.4: Correlation in relation to ROCE

\begin{tabular}{lcccccccc}
\hline & ROCE & SIZE & CAPITAL & LOAN & DEPOSITS & GDP & INF & MC \\
\hline ROCE & 1 & & & & & & & \\
SIZE & -0.115 & 1 & & & & & & \\
CAPITAL & -0.558 & 0.102 & 1 & & & & & \\
LOAN & -0.326 & 0.292 & -0.326 & 1 & & & & \\
DEPOSITS & -0.125 & 0.312 & 0.256 & 0.125 & 1 & & & \\
GDP & 0.012 & -0.365 & 0.236 & 0.362 & 0.145 & 1 & & \\
INF & 0.115 & 0.189 & -0.362 & -0.124 & 0.01 & -0.889 & 1 & \\
MC & -0.245 & 0.256 & 0.365 & 0.002 & 0.258 & 0.254 & -0.365 & 1 \\
\hline
\end{tabular}

\subsection{Regression Model}

The value of R-squared adjusted is 0.54 , which indicates that $54 \%$ variation in dependent variable is explained by the independent variables of research. And $46 \%$ change in the dependent variable remains unexplained by the independent variables. The value of F-statistic is 4.481 , which is more significant invalidating and stability model concern with the research.

\section{Conclusion}

Current study examined features of Pakistani banks. The data were taken from the period of 2005 to 2015. The factors which were taken are bank's internal and external factors. These factors, internal \& external, impact banks profitability level. Hypothesis one examined how microeconomic factors impact profitability of banks. On the other hand, hypothesis two indicated how macroeconomic bank factors have an effect on the banks profitability. This study is basi- 
Table 4.5: Regression Model

\begin{tabular}{ll}
\hline Variables & Coefficients \\
\hline SIZE & $0.641^{*}$ \\
Constant & $-12.79^{*}$ \\
LOAN & 0.234 \\
CAPITAL & -4.56 \\
GDP & $0.445^{*}$ \\
DEPOSITS & $0.141^{* *}$ \\
MC & -0.16 \\
INF & $0.161^{* *}$ \\
R-Squared & 0.63 \\
Adjusted R-Squared & 0.542 \\
F-Statistics & $4.481^{*}$ \\
\hline
\end{tabular}

*significance level at 0.01

**significance level at 0.05

cally about the determinations of banks profitability. For this reasons two main determinants are taken, i.e. internal \& external determinant of banks profitability. Internal determinants are particular to the banks managers; whereas external determinants are outside of the banks. Both the hypotheses had been accepted.

\subsection{Recommendations}

1. The capitalization of banks must be stimulated in a way that banks can improve their performance and growth rate.

2. The bank managers must adopt the policies regarding Well-organized \& active liquidity management system. Mostly banks are less profitable when they are more liquid. So bank managers should adopt policies accordingly.

3. The credit risk environment in the banks mostly becomes the source of decreased profitability; therefore, bank managers and credit officers should provide policies \& strategies that make the environment credit risk-free.

4. Banks should take cooperative \& elementary steps for building a capacity of Information Technology (IT) employees to decrease overreliance on foreign advisors, who demand offensive fee for software license and upholding contract.

\section{References}

Aburime, T. (2008). Impact of share capitalization on bank profitability in nigeria. International
Journal of Nigerian Studies and Development, 14:520.

Albert, S. (2015). Us bank holding companies: 
Structure of activities and performance through the cycles. International Review of Financial Analysis, 42:253-269.

Athanasoglou, P. P., Brissimis, S. N., and Delis, M. D. (2008). Bank-specific, industry-specific and macroeconomic determinants of bank profitability. Journal of international financial Markets, Institutions and Money, 18(2):121-136.

Bawumia, M. and Owusu-Danso, T. (2008). African financial reform: Ghanas reforms transform its financial sector. IMF Survey, 37(006).

Bourke, P. (1989). Concentration and other determinants of bank profitability in europe, north america and australia. Journal of Banking $\mathcal{E}$ Finance, 13(1):65-79.

Chatterjee, S., Das, P., and Gupta, A. (2014). The anatomy of profitability, efficiency and productivity of regional rural banks in selected backward districts of west bengal: a panel data investigation.

Chioma, O. and Orga, C. (NA). The impact of consolidation on the performance of banks in nigeria-profitability perspective (2004-2012).

Davydenko, A. (2010). Determinants of bank profitability in ukraine. Undergraduate Economic Review, $7(1): 2$.

Demirgüç-Kunt, A. and Huizinga, H. (1999). Determinants of commercial bank interest margins and profitability: some international evidence. The World Bank Economic Review, 13(2):379-408.

Ertekin, N., Shulman, J. D., and Chen, H. (2019). On the profitability of stacked discounts: Identifying revenue and cost effects of discount framing. Marketing Science, 38(2):317-342.

Greene, W. H. (2008). The econometric approach to efficiency analysis. The measurement of productive efficiency and productivity growth, 1(1):92-250.

Gyamerah, I. A. and Amoah, B. (2015). Determinants of bank profitability in ghana. International Journal of Accounting and Financial Reporting, 5(1):173-187.
Hosni, W., Lancon, F., et al. (2011). Apple value chain analysis. Working Paper-National Agricultural Policy Center, (48).

Jiang, G., Tang, N., Law, E., and Sze, A. (2003). The profitability of the banking sector in hong kong. Hong Kong Monetary Authority Quarterly Bulletin, 3(36):5-14.

Krakah, A. and Ameyaw, A. (2010). The determinants of banks profitability in ghana, the case of merchant bank ghana limited $(\mathrm{mbg})$ and ghana commercial bank ( $\mathrm{gcb})$. Unpublished MBA Thesis, Blekinge Institute of Technology.

McClendon, H. and Buckner, E. B. (2007). Distressing situations in the intensive care unit: a descriptive study of nurses' responses. Dimensions of critical care nursing, 26(5):199-206.

Mill, R., Chambers Jr, R., Craig, E., Schneider, M., Fitzgerald, R., Hollenback, H., Hansen, J., Jankura, D., Smith, W., et al. (1986). Operations management. In The practice of hospitality management II. Profitability in a changing environment. World hospitality congress II, Boston, Massachusetts, March 25-28, 1984, pages 149-189. AVI Publishing Company, Inc.

Radian, R. (2019). Semi-quantum money. In Proceedings of the 1st ACM Conference on Advances in Financial Technologies, pages 132-146.

Rasiah, D. (2010). Review of literature and theories on determinants of commercial bank profitability. Journal of Performance management, 23(1).

Revel, J. (1979). Inflation and financial institution. Financial Times. www. googlescholar. org. Retrieved, 26(2):2020.

Tan, Y. and Floros, C. (2012). Bank profitability and inflation: the case of china. Journal of Economic Studies.

Torre Olmo, B., Cantero Saiz, M., and Sanfilippo Azofra, S. (2021). Sustainable banking, market power, and efficiency: Effects on banks profitability and risk. Sustainability, 13(3):1298.

Vong, P. I. and Chan, H. S. (2009). Determinants of bank profitability in macao. Macau Monetary Research Bulletin, 12(6):93-113. 